\title{
VARIETAL CHANGES IN TWO FINNISH ALSIKE CLOVER VARIETIES GROWN FOR SEED IN THE USA
}

\author{
Otto Valle ${ }^{1}$ †, Kirsti ÄyräväInen ${ }^{1}$, , and C. S. Garrison ${ }^{2}$ \\ Department of Plant Husbandry, University of Helsinki ${ }^{1}$
}

Plant Science Research Division, Agricultural Research Service, U. S. Department of Agriculture')

Received July 27, 1971

\begin{abstract}
Two Finnish alsike clover varieties, diploid Tammisto and tetraploid Iso, were grown for seed at different locations in the USA for several successive generations. The seed lots were tested in single-plant and forage production trials in Finland to reveal possible varietal changes caused by producing seed in foreign environments. - Many of the Tammisto alsike lots produced in the USA had more early-type plants than the Finnish basic seed. In contrast the USA grown Iso lots which differed from the basic seed had lower average growth type indices and fewer flowering plants. - Increase in earliness was supposed to result from efficient pollination during early, sparse flowering, decrease in earliness from the fact that alsike clover is a species especially prone to shedding its seeds as soon as they mature.

In spaced-plant tests many of the USA lots produced progenies with less winterhardiness than those from the basic seed lot. The poorest overwintering was recorded for the lots from the southern locations. There were no appreciable differences between the four production localities in the United States in terms of other characteristics of the two varieties. - With successive generations of increase no progressive varietal changes were found to occur. Seed lots harvested from the same plot for two or more years did not differ from each other.

Forage yield trials comparing the most advanced generation seed lots from the USA with basic seed did not reveal any consistently significant differences.
\end{abstract}

Alsike clover (Trifolium hybridum L.) is grown in leys in Finland as the second most important legume after red clover. Cultivation of the species is limited by its relatively low yielding capacity as compared with red clover and its susceptibility to drought due to the weak and shallow root system. Since tetraploid varieties, which are more winter-hardy and higher-yielding than diploids, have been released on the market, the prospects for alsike clover to gain a more prominent position in Finnish forage production have improved considerably. On wet humus and peat soils the tetraploid alsike clover varieties are capable of competing with red clover.

There are two Finnish bred varieties of alsike, the diploid Tammisto and the tetraploid Iso. Their domestic cultivation is also limited by difficulties in seed production. Of the foreign varieties, Swedish tetraploid Tetra has proved persistent and high-yielding under Finnish conditions (RavantTi 1959), yet its seed has not been available due to seed pro-

This study was supported by grants No. FG-Fi-109-60 and FG-Fi-144 of P. L. 480 currencies from the U. S. Department of Agriculture. 
Table 1. Daylength and weather data for the four USA locations producing Finnish alsike clover seed and for Tikkurila, Finland.

\begin{tabular}{|c|c|c|c|c|c|c|}
\hline \multirow[b]{2}{*}{ Location } & \multicolumn{6}{|c|}{ Length of day (h. min.) on the 15 th of each month } \\
\hline & April & May & June & July & Aug. & Sept. \\
\hline Prosser & 13.32 & 14.58 & 15.45 & 15.25 & 14.11 & 12.36 \\
\hline $\left.\begin{array}{l}\text { Tehachapi } \\
\text { Shafter }\end{array}\right\}$ & 13.03 & 13.59 & 14.30 & 14.18 & 13.30 & 12.26 \\
\hline Tucson & 12.57 & 13.47 & 14.14 & 14.04 & 13.20 & 12.24 \\
\hline \multirow[t]{3}{*}{ Tikkurila } & 14.28 & 17.04 & 18.45 & 18.02 & 15.38 & 12.53 \\
\hline & \multicolumn{6}{|c|}{ Monthly mean temperature, ${ }^{\circ} \mathrm{C}$} \\
\hline & April & May & June & July & Aug. & Sept. \\
\hline Prosser & 10.7 & 14.8 & 18.2 & 21.6 & 20.7 & 16.9 \\
\hline Tehachapi & 10.3 & 13.5 & 18.3 & 22.4 & 21.1 & 17.8 \\
\hline Shafter & 16.6 & 20.4 & 24.1 & 27.8 & 26.3 & 23.1 \\
\hline Tucson & 18.8 & 23.1 & 28.2 & 30.2 & 28.4 & 26.9 \\
\hline \multirow[t]{3}{*}{ Tikkurila } & 2.9 & 9.3 & 14.3 & 17.0 & 15.4 & 10.4 \\
\hline & \multicolumn{6}{|c|}{ Monthly mean precipitation, $\mathrm{mm}$} \\
\hline & April & May & June & July & Aug. & Sept. \\
\hline Prosser & 14 & 15 & 17 & 4 & 5 & 9 \\
\hline Tehachapi & 24 & 13 & 3 & 1 & 4 & 7 \\
\hline Shafter & 22 & 7 & 1 & 0 & 1 & 1 \\
\hline Tucson & 7 & 3 & 7 & 52 & 73 & 25 \\
\hline Tikkurila & 42 & 40 & 48 & 73 & 75 & 69 \\
\hline
\end{tabular}

duction problems in Sweden. In the 1960's seed increase experiments with Tammisto and Iso were started in the states of Washington, California and Arizona, USA, to determine whether seed production was practicable in foreign countries for export to Finland. Preliminary experiments had been carried out in the USA and evaluated in trials in Finland before (VAlle and Garrison 1959). Producing seed of a variety under conditions differing from those in its region of origin may induce changes which adversely affect its agricultural value where it is grown for forage. Thus, in addition to the experimental seed increases of Tammisto and Iso alsike clovers in the USA, a number of evaluation and forage production trials were initiated in Finland. This paper presents results of single-plant evaluation trials and forage production tests carried out with Tammisto and Iso alsike clover seed produced in the USA at the Department of Plant Husbandry of Agricultural Research Centre, Tikkurila, the Department of Plant Husbandry of the University of Helsinki, Experimental Farm Viik, and the Experimental Farm Länsi-Hahkiala, Hauho, in the years $1964-70$.

\section{Materials and methods}

Seed production in the USA. Seed of Finnish alsike clover was produced at four different locations in the USA: Prosser, Wash. (lat. $\left.46^{\circ} 15^{\prime} \mathrm{N}\right)$, Tehachapi $\left(35^{\circ} 8^{\prime} \mathrm{N}\right.$ ) and Shafter $\left(35^{\circ} 23^{\prime} \mathrm{N}\right)$, Cal., and Tucson, Ariz. ( $\left.32^{\circ} 30^{\prime} \mathrm{N}\right)$. Table 1 presents daylength 
and weather data for these locations and shows clearly the great basic differences between the environmental conditions in Tucson and Shafter on one hand and Finland on the other. Tehachapi, situated on approximately the same latitude as Shafter but in a mountain valley (elevation $1200 \mathrm{~m}$ above sea level; Shafter $110 \mathrm{~m}$ ) has a climate more closely resembling that of Prosser, Washington.

At the four experimental locations in the USA alsike clover seed was produced under irrigation. Consequently the serious hazard of excessive moisture during the period of seed ripening and harvest, all too familiar in Finland, seldom occurs at these American locations.

Specified data on the USA productions of Finnish alsike clover seed are presented in Table 2. At Prosser, the average seed plot size was $500 \mathrm{~m}^{2}$, in Shafter, Tehachapi and Tucson $120-200 \mathrm{~m}^{2}$. The seed increase plots were sown either in spring or fall. From spring-sown plots the first seed crop was usually harvested in the fall of the planting year. The plots were harvested for seed in two years. One seed crop a year was generally taken; the third-generation Tammisto in Tucson was harvested twice in both of the two crop years (main crop harvest in July and aftermath harvest in early October). All the Tucson plantings yielded very little seed; the aftermath harvests only gave 12 and $18 \mathrm{~kg} / \mathrm{ha}$. Some fairly satisfactory seed yields of both Tammisto and Iso were obtained at Shafter and Tehachapi although even there most yields were poor. Prosser was found the most suitable location for production of alsike clover seed.

Seed set observations on Tammisto and Iso in the USA (Table 3) revealed no variation due to location of production. For each variety the average numbers of florets and seeds per flower head were approximately the same at all locations. There were no significant differences in numbers of flower heads per area unit.

Evaluation in Fin land. Evaluation trials with US-grown Tammisto and Iso alsike clover seed lots were carried out in Finland from 1963 to 1970 except for 1965. The present paper reports on the results of the years 1964, and 1968-70. Trials in these years included the 3rd and 4th-generation productions as well as one lst and 2nd-generation lot for each variety and location. In 1964 the USA grown lots were compared with the original Finnish basic lots. Since the latter were produced as early as 1957 (Tammisto) and 1959 (Iso), they were replaced in the later trials (1968 - 69) by Finnish first-generation lots grown from the basic lots in 1964 and 1965. Separate evaluation trials showed the first-generation Finnish lots to be similar in characteristics to the original basic seed.

In 1964 the trials were situated at the Department of Plant Husbandry, Tikkurila $\left(60^{\circ} 18^{\prime} \mathrm{N}\right)$, in $1968-70$ on the University Farm Viik $\left(60^{\circ} 13^{\prime} \mathrm{N}\right)$. The 1964 trials were established by sowing the seed directly to the field in rows $50 \mathrm{~cm}$ apart and subsequently thinning the stands to $35 \mathrm{~cm}$ plant distances within the row. For the 1968-69 trials seed was sown in flats in greenhouse in early April. The seedlings were transplanted to plastic "multipot» growing trays (pot diameter $35 \mathrm{~mm}$ ) when about one month old and to the field in late May-early June. Plant distances were $50 \times 50 \mathrm{~cm}$. In setting up the trials a randomized block design was used with four replications in 1964 and 1968, and six in 1969. Total numbers of plants per seed lot in the three years were 256, 176 and 144, respectively.

Several growth type observations were made on single plants during the first summer following planting. The evaluation scale used for red clover in similar trials by VALLE and Garrison (1965) was modified slightly for alsike clover. It included the following plant type categories: 
Table 2. Number of seed lots, harvest year and seed yield $\mathrm{kg} / \mathrm{ha}$ of Tammisto and Iso alsike clover produced in the USA.

\begin{tabular}{|c|c|c|c|c|c|c|c|}
\hline \multirow{3}{*}{ Location } & \multirow{3}{*}{$\begin{array}{c}\text { Harvest } \\
\left.\text { year }^{1}\right)\end{array}$} & \multirow{3}{*}{$\begin{array}{l}\text { Total } \\
\text { number of } \\
\text { seed lots }\end{array}$} & \multicolumn{5}{|c|}{ Seed yield kg/ha } \\
\hline & & & \multicolumn{4}{|c|}{ Generation } & \multirow[b]{2}{*}{ Average } \\
\hline & & & I & II & III & IV & \\
\hline \multicolumn{8}{|c|}{ Tammisto alsike clover } \\
\hline \multirow{3}{*}{ Prosser } & 0 & 3 & - & 128 & 350 & 215 & 231 \\
\hline & 1 & 4 & 587 & 256 & 590 & 336 & 442 \\
\hline & 2 & 1 & - & - & 29 & - & 29 \\
\hline \multirow[t]{2}{*}{ Tehachapi } & 1 & 4 & 319 & 269 & 177 & 138 & 226 \\
\hline & 2 & 2 & 128 & 9 & - & - & 69 \\
\hline \multirow[t]{3}{*}{ Shafter } & 0 & 1 & 155 & - & - & - & 155 \\
\hline & 1 & 3 & 158 & 72 & 221 & - & 150 \\
\hline & 2 & 2 & - & 93 & 231 & - & 162 \\
\hline \multirow[t]{5}{*}{ Tucson } & 1 & 3 & 15 & 168 & 69 & - & 84 \\
\hline & $\left.1^{2}\right)$ & 1 & - & - & 12 & - & 12 \\
\hline & 2 & 3 & 30 & 116 & 27 & - & 58 \\
\hline & $\left.2^{2}\right)$ & 1 & - & - & 8 & - & 8 \\
\hline & ke clover & & & & & & \\
\hline \multirow[t]{2}{*}{ Prosser } & 0 & 4 & 155 & 180 & 161 & 402 & 225 \\
\hline & 1 & 4 & 257 & 244 & 165 & 382 & 262 \\
\hline \multirow[t]{3}{*}{ Tehachapi } & 0 & 1 & 13 & - & - & - & 13 \\
\hline & 1 & 5 & $25+59$ & 433 & 85 & 118 & 144 \\
\hline & 2 & 2 & - & 203 & - & 59 & 131 \\
\hline \multirow[t]{3}{*}{ Shafter } & 0 & 2 & 44 & 49 & - & - & 47 \\
\hline & 1 & 4 & 16 & 277 & 262 & 357 & 228 \\
\hline & 2 & 2 & - & - & 45 & 30 & 38 \\
\hline \multicolumn{8}{|c|}{$\begin{array}{l}\text { 1) Harvest year } 0=\text { year of planting; } \\
\text { planting year. } \\
\text { 2) Second harvest in the same year. }\end{array}$} \\
\hline \multirow[b]{2}{*}{ Location } & \multirow{2}{*}{$\begin{array}{l}\text { Number of } \\
\text { seed lots } \\
\text { tested }\end{array}$} & \multicolumn{4}{|c|}{ Average number of } & \multirow{2}{*}{\multicolumn{2}{|c|}{$\begin{array}{c}1000 \text { seed } \\
\text { weight, } \\
\mathrm{g}\end{array}$}} \\
\hline & & $\begin{array}{l}\text { heads } \\
\text { per } \mathrm{m}^{2}\end{array}$ & $\begin{array}{c}\text { florets } \\
\text { per head }\end{array}$ & $\begin{array}{c}\text { seeds } \\
\text { per head }\end{array}$ & $\begin{array}{c}\text { seeds } \\
\text { per floret }\end{array}$ & & \\
\hline \multicolumn{8}{|c|}{ Tammisto alsike clover } \\
\hline Prosser & 8 & $1194 \mathrm{a}$ & $63 \mathrm{ab}$ & $88 \mathrm{c}$ & $1.37 \mathrm{~b}$ & & $68 \mathrm{~b}$ \\
\hline Tehachapi & 6 & 906 a & $59 \mathrm{a}$ & $79 \mathrm{bc}$ & $1.32 \mathrm{~b}$ & & 72 b \\
\hline Shafter & 6 & 657 a & 61 a & $90 \mathrm{c}$ & $1.51 \mathrm{~b}$ & & $74 \mathrm{~b}$ \\
\hline \multirow[t]{2}{*}{ Tucson } & 7 & No data & $60 \mathrm{a}$ & $82 \mathrm{bc}$ & $1.34 \mathrm{~b}$ & & 61 a \\
\hline & lsike clover & & & & & & \\
\hline Prosser & 8 & $1153 \mathrm{a}$ & $69 \mathrm{~b}$ & $64 \mathrm{ab}$ & 0.91 a & & $07 \mathrm{c}$ \\
\hline Tehachapi & 8 & 704 a & $63 \mathrm{ab}$ & 53 a & $0.82 \mathrm{a}$ & & $07 \mathrm{c}$ \\
\hline Shafter & 8 & 886 a & $63 \mathrm{ab}$ & $52 \mathrm{a}$ & $0.82 \mathrm{a}$ & & $08 \mathrm{c}$ \\
\hline
\end{tabular}

Means followed by the same letter are not different at the $5 \%$ level of significance. 
$1=$ Rosette only

$2 \mathrm{a}=$ Tiller formation just begun ( 1 internode)

$2=$ Rosette with tillers with 2 internodes

3 = Rosette with tillers with 3 or more internodes

$4 \mathrm{a}=$ Large rosette, stems with flower buds

4 = Large rosette, stems with open flowers

$5 \mathrm{a}=$ Small rosette, stems with flower buds

$5=$ Small rosette, stems with open flowers

$6 \mathrm{a}=$ No rosette, stems with flower buds

$6=$ No rosette, stems with open flowers.

Individual plant type observations were made on different dates during the first summer. An average growth type figure was calculated for each lot for each observation date. Also the percentages of flowering plants were determined. Only results from the observation date that most clearly show differences between seed lots are given in Tables 4-9. The earlier observations were more definitive. In the later ones with increasing growth and more abundant flowering, differences between the lots tended to disappear. In 1968 the plants were cut in late summer and their individual fresh weights as well as numbers of stems and flower heads per plant were determined. The size of each individual leaf rosette was assessed about one month later to show the aftermath growth. The 1968 trial was evaluated for winter survival in the spring of 1969 ; the date of beginning of flowering was subsequently recorded for each plant separately. The 1969 trial was sprayed with PCNB several times during the first fall in order to secure successfull overwintering. The resulting high rate of survival made it possible to carry out accurate flowering observations in the second season.

Forage production trials, consisting of the Finnish standard and three seed lots from the USA, were established for the two alsike clover varieties in 1968. The locations for these trials were University Farm Viik $\left(60^{\circ} 13^{\prime} \mathrm{N}\right)$ and Experimental Farm Länsi-Hahkiala at Hauho $\left(61^{\circ} 9^{\prime} \mathrm{N}\right)$. Seeds were drill-sown in rows spaced $15 \mathrm{~cm}$ apart under a nurse crop of barley at Viik and oats at Länsi-Hahkiala. Plot size was $10 \mathrm{~m}^{2}$. There were 6 replications at Viik and 4 at Länsi-Hahkiala. The trials were harvested twice in each of two years following the planting year. Fresh forage yields were weighed and tons/ha calculated. Dry matter and crude protein contents were determined for one or two replications. Winter survival was also recorded.

The experimental data were statistically analysed and significant differences between means determined by Duncan's multiple range test.

\section{Results}

The results of the various years were surprisingly different in Tammisto alsike clover. In the 1964 trials with first and second-generation lots from Prosser, Tehachapi and Tucson most of the USA lots showed higher proportions of early-type plants with small leaf rosette than the basic seed lot (Table 4). In later trials, on the other hand, the growth type means for most of the lots produced in the USA did not differ significantly from that for the basic lot. In the 1968 trial (Table 5) the USA lots had smaller means than the basic lot indicating later flowering types. However, in the 1969 trial (Table 6) the growth type 
Table 4. Results from spaced-plant evaluation trials with Tammisto alsike clover, 1964. Trials established in 1964 .

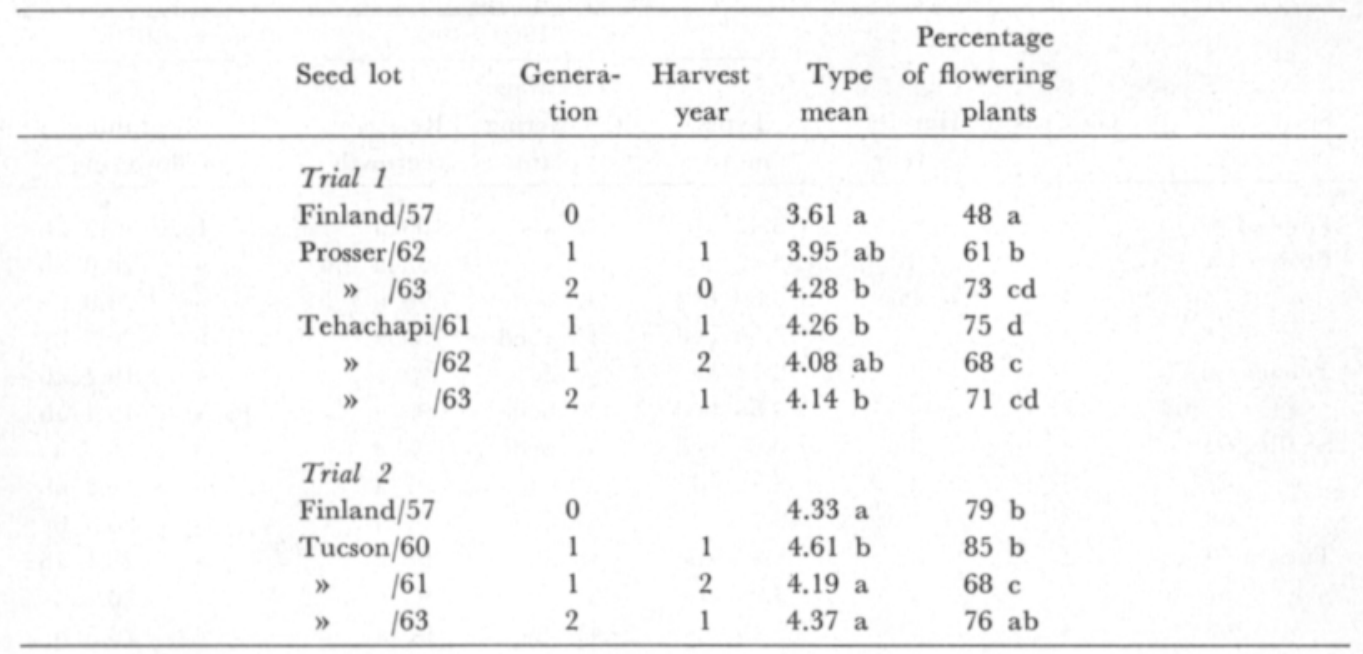

Means followed by the same letter within trial are not different at the $5 \%$ level of significance.

Table 5. Results from spaced-plant evaluation trials with Tammisto alsike clover, 1968 and 1969. Trials established in 1968.

\begin{tabular}{|c|c|c|c|c|c|c|c|c|c|c|c|}
\hline \multirow[b]{2}{*}{ Seed lot } & \multirow[b]{2}{*}{$\begin{array}{c}\text { Genera- } \\
\text { tion }\end{array}$} & \multirow[b]{2}{*}{$\begin{array}{c}\text { Harvest } \\
\text { year }\end{array}$} & \multicolumn{6}{|c|}{1968} & \multicolumn{3}{|c|}{1969} \\
\hline & & & $\begin{array}{l}\text { Type } \\
\text { mean }\end{array}$ & $\begin{array}{c}\text { Percentage } \\
\text { of flowering } \\
\text { plants }\end{array}$ & $\begin{array}{c}\text { Fresh } \\
\text { weight } \\
\mathrm{g}\end{array}$ & $\begin{array}{c}\text { Number } \\
\text { of } \\
\text { stems }\end{array}$ & $\begin{array}{c}\text { Number of } \\
\text { flower } \\
\text { heads }\end{array}$ & $\begin{array}{l}\text { Relative } \\
\text { regrowth }\end{array}$ & $\begin{array}{c}\text { Winter } \\
\text { survival } \\
\%\end{array}$ & $\begin{array}{l}\text { Beg } \\
\text { of flor }\end{array}$ & $\begin{array}{l}\text { ginning } \\
\text { wering }\end{array}$ \\
\hline \multicolumn{12}{|l|}{ Trial 1} \\
\hline Finland/64 & 0 & & $2.50 \mathrm{a}$ & 23 a & $418 \mathrm{a}$ & 29 a & 205 a & $100 \mathrm{a}$ & 59 c & June & 20.9 a \\
\hline Prosser/66 & 3 & 1 & $2.34 \mathrm{a}$ & 21 a & 418 a & 32 a & $187 \mathrm{a}$ & $103 \mathrm{a}$ & 52 bc & " & $21.9 \mathrm{a}$ \\
\hline$m \quad / 67$ & 3 & 2 & $2.21 \mathrm{a}$ & 19 a & 397 a & $34 \mathrm{a}$ & 185 a & $101 \mathrm{a}$ & $50 \mathrm{bc}$ & $"$ & $21.1 \mathrm{a}$ \\
\hline /67 & 4 & 0 & $2.24 \mathrm{a}$ & 19 a & 421 a & 29 a & 220 a & $100 \mathrm{a}$ & $51 \mathrm{bc}$ & $m$ & 21.4 a \\
\hline Tehachapi/65 & 3 & 1 & $2.24 \mathrm{a}$ & $18 \mathrm{a}$ & 409 a & $27 \mathrm{a}$ & 204 a & 99 a & $49 \mathrm{bc}$ & $"$ & $21.8 \mathrm{a}$ \\
\hline Shafter $/ 65$ & 2 & 1 & $2.46 \mathrm{a}$ & 23 a & 408 a & 28 a & 208 a & 98 a & $39 \mathrm{ab}$ & $n$ & $21.2 \mathrm{a}$ \\
\hline$" \quad / 67$ & 3 & 1 & $2.15 \mathrm{a}$ & 15 a & 395 a & 28 a & 204 a & 98 a & 34 a & $n$ & 22.1 a \\
\hline \multicolumn{12}{|l|}{ Trial 2} \\
\hline Finland/64 & 0 & & $2.21 \mathrm{a}$ & 20 a & 316 a & $20 \mathrm{a}$ & 37 a & $100 \mathrm{~b}$ & & & \\
\hline Tucson/63 & 2 & 1 & $2.36 \mathrm{ab}$ & 23 a & 315 a & $17 \mathrm{a}$ & 28 a & $95 \mathrm{~b}$ & $\underset{\widetilde{J}}{\mathbb{J}}$ & & $\overbrace{\pi}^{\pi}$ \\
\hline$\Rightarrow \quad / 67$ & 3 & $\left.1^{1}\right)$ & $2.64 \mathrm{~b}$ & $35 \mathrm{~b}$ & 311 a & $19 \mathrm{a}$ & 29 a & $90 \mathrm{ab}$ & $\frac{\text { गु }}{0}$ & & ชู \\
\hline$" \quad / 67$ & 3 & $\left.1^{2}\right)$ & $2.21 \mathrm{a}$ & $11 \mathrm{a}$ & 312 a & $19 \mathrm{a}$ & 35 a & 81 a & z & & ํㅜㄴ \\
\hline
\end{tabular}

1) = Early harvest 2) = Late harvest

Means followed by the same letter within trial are not different at the $5 \%$ level of significance.

means for the USA lots were generally larger than the mean for the basic lot. In the tetraploid Iso no changes in growth characteristics could be seen in the first two USA generations (Table 7) and significant differences from the basic seed were still quite rare in the 
Table 6. Results from spaced-plant evaluation trial with Tammisto alsike clover, 1969 and 1970. Trial established in 1969.

\begin{tabular}{|c|c|c|c|c|c|c|c|}
\hline \multirow[b]{2}{*}{ Seed lot } & \multirow[b]{2}{*}{$\begin{array}{c}\text { Genera- } \\
\text { tion }\end{array}$} & \multirow[b]{2}{*}{$\begin{array}{c}\text { Harvest } \\
\text { year }\end{array}$} & \multicolumn{3}{|c|}{1969} & \multicolumn{2}{|c|}{1970} \\
\hline & & & $\begin{array}{l}\text { Type } \\
\text { mean }\end{array}$ & $\begin{array}{c}\text { Percentage } \\
\text { of flowering } \\
\text { plants }\end{array}$ & $\begin{array}{l}\text { Relative } \\
\text { regrowth }\end{array}$ & $\begin{array}{r}\text { Bes } \\
\text { of flo }\end{array}$ & $\begin{array}{l}\text { ginning } \\
\text { wering }\end{array}$ \\
\hline Finland/64 & 0 & & $3.42 \mathrm{ab}$ & 42 abc & $100 \mathrm{a}$ & June & $19.2 \mathrm{ab}$ \\
\hline Prosser/66 & 3 & 1 & $3.32 \mathrm{a}$ & 32 a & 95 a & $"$ & $20.0 \mathrm{ab}$ \\
\hline " /67 & 4 & 0 & $3.60 \mathrm{bcd}$ & 52 bcde & 96 a & $"$ & $20.0 \mathrm{ab}$ \\
\hline$" / 68$ & 4 & 1 & $3.50 \mathrm{abc}$ & 44 abcd & $100 \mathrm{a}$ & 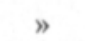 & $20.7 \mathrm{~b}$ \\
\hline Tehachapi/65 & 3 & 1 & $3.78 \mathrm{de}$ & $56 \mathrm{de}$ & 99 a & $"$ & $19.2 \mathrm{ab}$ \\
\hline$" \quad / 68$ & 4 & 1 & $3.66 \mathrm{bcd}$ & 50 bcde & 99 a & 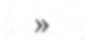 & $19.4 \mathrm{ab}$ \\
\hline Shafter/65 & 2 & 1 & $3.66 \mathrm{bcd}$ & 51 bcde & 93 a & $"$ & $18.7 \mathrm{a}$ \\
\hline " $\quad / 67$ & 3 & 1 & $3.72 \mathrm{~cd}$ & 54 cde & $97 \mathrm{a}$ & $"$ & $19.2 \mathrm{ab}$ \\
\hline$\Rightarrow \quad / 68$ & 3 & 2 & $3.71 \mathrm{~cd}$ & 51 bcde & 97 a & $"$ & $20.3 \mathrm{~b}$ \\
\hline Tucson/63 & 2 & 1 & $3.47 \mathrm{abc}$ & $40 \mathrm{ab}$ & $98 \mathrm{a}$ & $n$ & $20.1 \mathrm{ab}$ \\
\hline » /67 & 3 & 1 & 3.96 ef & 62 ef & 93 a & $"$ & $20.4 \mathrm{~b}$ \\
\hline \# $/ 68$ & 3 & $\left.2^{1}\right)$ & $3.49 \mathrm{abc}$ & $41 \mathrm{abc}$ & $100 \mathrm{a}$ & " & $20.5 \mathrm{~b}$ \\
\hline$\Rightarrow \quad / 68$ & 3 & $\left.2^{2}\right)$ & $4.17 \mathrm{f}$ & $69 \mathrm{f}$ & 97 a & $"$ & $20.4 \mathrm{~b}$ \\
\hline
\end{tabular}

1) = Early harvest 2) = Late harvest

Means followed by the same letter are not different at the $5 \%$ level of significance.

Table 7. Results from spaced-plant evaluation trial with Iso alsike clover, 1964. Trial established in 1964.

\begin{tabular}{ccccc}
\hline Seed lot & $\begin{array}{c}\text { Genera- } \\
\text { tion }\end{array}$ & $\begin{array}{c}\text { Harvest } \\
\text { year }\end{array}$ & $\begin{array}{c}\text { Type } \\
\text { mean }\end{array}$ & $\begin{array}{c}\text { Percentage } \\
\text { of flowering } \\
\text { plants }\end{array}$ \\
\hline Finland/59 & 0 & & $3.94 \mathrm{a}$ & $60 \mathrm{a}$ \\
Prosser/62 & 1 & 1 & $4.15 \mathrm{a}$ & $66 \mathrm{a}$ \\
" $/ 63$ & 2 & 0 & $3.98 \mathrm{a}$ & $63 \mathrm{a}$ \\
Tehachapi/62 & 1 & 1 & $3.95 \mathrm{a}$ & $59 \mathrm{a}$ \\
Shafter/61 $/ 63$ & 2 & 1 & $4.02 \mathrm{a}$ & $66 \mathrm{a}$ \\
" /63 & 1 & 0 & $3.86 \mathrm{a}$ & $59 \mathrm{a}$ \\
\hline
\end{tabular}

Means followed by the same letter are not different at the $5 \%$ level of significance.

later generations (Tables 8 and 9). It is worth noting, however, that while many of the USA lots of diploid Tammisto alsike showed a slight tendency towards higher growth type indices and earlier flowering as compared to the basic seed, the tendency for the tetraploid Iso was the reverse, towards lower growth types and scarcer flowering.

Seed sources within either variety did not show any appreciable variation in fresh weight per plant (Tables 5 and 8). Differences in numbers of stems and flower heads were likewise small and insignificant.

Aftermath growth of the USA lots was, with a few exceptions, similar to that of the 
Table 8. Results from spaced-plant evaluation trial with Iso alsike clover, 1968 and 1969. Trial established in 1968.

\begin{tabular}{|c|c|c|c|c|c|c|c|c|c|c|c|}
\hline \multirow[b]{2}{*}{ Seed lot } & \multirow[b]{2}{*}{$\begin{array}{c}\text { Genera- } \\
\text { tion }\end{array}$} & \multirow[b]{2}{*}{$\begin{array}{c}\text { Harvest } \\
\text { year }\end{array}$} & \multicolumn{6}{|c|}{1968} & \multicolumn{3}{|c|}{1969} \\
\hline & & & $\begin{array}{l}\text { Type } \\
\text { mean }\end{array}$ & $\begin{array}{l}\text { Percentage } \\
\text { of flowering } \\
\text { plants }\end{array}$ & $\begin{array}{c}\text { Fresh } \\
\text { weight } \\
\text { g }\end{array}$ & $\begin{array}{c}\text { Number } \\
\text { of } \\
\text { stems }\end{array}$ & $\begin{array}{l}\text { Number of } \\
\text { flower } \\
\text { heads }\end{array}$ & $\begin{array}{l}\text { Relative } \\
\text { regrowth }\end{array}$ & $\begin{array}{c}\text { Winter } \\
\text { survival } \\
\%\end{array}$ & $\begin{array}{r}\text { Bes } \\
\text { of } \mathrm{flo}\end{array}$ & $\begin{array}{l}\text { eginning } \\
\text { owering }\end{array}$ \\
\hline Finland/64 & 0 & & $4.05 \mathrm{c}$ & $54 \mathrm{~b}$ & $450 \mathrm{ab}$ & 18 a & $161 \mathrm{a}$ & $100 \mathrm{a}$ & $66 \mathrm{c}$ & June & $22.5 \mathrm{ab}$ \\
\hline Prosser/66 & 3 & 1 & $3.86 \mathrm{bc}$ & $47 \mathrm{~b}$ & 422 a & 24 a & $166 \mathrm{a}$ & 96 a & $58 \mathrm{bc}$ & $"$ & $22.6 \mathrm{ab}$ \\
\hline$" \quad / 67$ & 4 & 0 & $3.72 \mathrm{bc}$ & $39 \mathrm{ab}$ & $440 \mathrm{ab}$ & 20 a & $160 \mathrm{a}$ & $99 \mathrm{a}$ & $53 \mathrm{ab}$ & $"$ & $22.9 \mathrm{~b}$ \\
\hline Tehachapi/65 & 3 & 1 & $3.61 \mathrm{ab}$ & $39 \mathrm{ab}$ & $447 \mathrm{ab}$ & 22 a & $153 \mathrm{a}$ & 99 a & $54 \mathrm{ab}$ & $"$ & $22.9 \mathrm{~b}$ \\
\hline$\Rightarrow \quad / 67$ & 4 & 1 & $4.02 \mathrm{c}$ & $54 \mathrm{~b}$ & $455 \mathrm{~b}$ & 24 a & 155 a & $100 \mathrm{a}$ & $53 \mathrm{ab}$ & $"$ & $22.4 \mathrm{ab}$ \\
\hline Shafter/65 & 3 & 1 & $3.38 \mathrm{a}$ & 26 a & $443 \mathrm{ab}$ & 23 a & 152 a & 98 a & $47 \mathrm{a}$ & $"$ & $22.0 \mathrm{ab}$ \\
\hline " $\quad / 67$ & 4 & 1 & $3.77 \mathrm{bc}$ & $43 \mathrm{~b}$ & $432 \mathrm{ab}$ & $21 \mathrm{a}$ & $162 \mathrm{a}$ & 97 a & $49 \mathrm{ab}$ & $"$ & $21.8 \mathrm{a}$ \\
\hline
\end{tabular}

Means followed by the same letter are not different at the $5 \%$ level of significance.

Table 9. Results from spaced-plant evaluation trial with Iso alsike clover, 1969 and 1970. Trial established in 1969.

\begin{tabular}{|c|c|c|c|c|c|c|}
\hline \multirow[b]{2}{*}{ Seed lot } & \multirow[b]{2}{*}{$\begin{array}{c}\text { Genera- } \\
\text { tion }\end{array}$} & \multirow[b]{2}{*}{$\begin{array}{c}\text { Harvest } \\
\text { year }\end{array}$} & \multicolumn{3}{|c|}{1969} & 1970 \\
\hline & & & $\begin{array}{l}\text { Type } \\
\text { mean }\end{array}$ & $\begin{array}{l}\text { Percentage } \\
\text { of flowering } \\
\text { plants }\end{array}$ & $\begin{array}{l}\text { Relative } \\
\text { regrowth }\end{array}$ & $\begin{array}{l}\text { Beginning } \\
\text { of flowering }\end{array}$ \\
\hline Finland/64 & 0 & & $3.92 \mathrm{~b}$ & $56 \mathrm{~b}$ & $100 \mathrm{~b}$ & June 20.1 a \\
\hline Prosser/66 & 3 & 1 & $3.77 \mathrm{ab}$ & $54 \mathrm{~b}$ & $97 \mathrm{ab}$ & " 20.2 a \\
\hline$" \quad / 67$ & 4 & 0 & $3.93 \mathrm{~b}$ & $60 \mathrm{~b}$ & $95 \mathrm{ab}$ & $\Rightarrow \quad 20.9$ a \\
\hline " /68 & 4 & 1 & $3.80 \mathrm{~b}$ & $54 \mathrm{~b}$ & $99 \mathrm{~b}$ & $\Rightarrow \quad 21.0 \mathrm{a}$ \\
\hline Tehachapi/65 & 3 & 1 & $3.54 \mathrm{a}$ & $37 \mathrm{a}$ & $98 \mathrm{ab}$ & $\Rightarrow \quad 20.9$ a \\
\hline$" \quad / 67$ & 4 & 1 & $3.90 \mathrm{~b}$ & $60 \mathrm{~b}$ & $97 \mathrm{ab}$ & $20.4 \mathrm{a}$ \\
\hline " $\quad / 68$ & 4 & 2 & $3.76 \mathrm{ab}$ & $51 \mathrm{~b}$ & 89 a & 20.9 a \\
\hline Shafter/65 & 3 & 1 & $3.82 \mathrm{~b}$ & $55 \mathrm{~b}$ & $96 \mathrm{ab}$ & $21.0 \mathrm{a}$ \\
\hline$" \quad / 67$ & 4 & 1 & $3.71 \mathrm{ab}$ & $48 \mathrm{ab}$ & $93 \mathrm{ab}$ & $21.0 \mathrm{a}$ \\
\hline$\Rightarrow \quad / 68$ & 4 & 2 & $3.89 \mathrm{~b}$ & $57 \mathrm{~b}$ & $94 \mathrm{ab}$ & $19.5 \mathrm{a}$ \\
\hline
\end{tabular}

Means followed by the same letter are not different at the $5 \%$ level of significance.

Finnish lots. Nevertheless the spaced plants of many USA lots overwintered significantly poorer than the Finnish ones (Tables 5 and 8). The Tammisto and Iso alsike lots from Shafter suffered the worst winter damages. Unfortunately no overwintering data are available for the Tammisto lots grown in Tucson where climatic conditions provided more severe selection pressures than those at Shafter.

There was some discrepancy in Tammisto alsike between the growth type figures of the first summer and the beginning of flowering in the second (Table 6). Many lots for which larger growth type means had been recorded in the planting year started their 


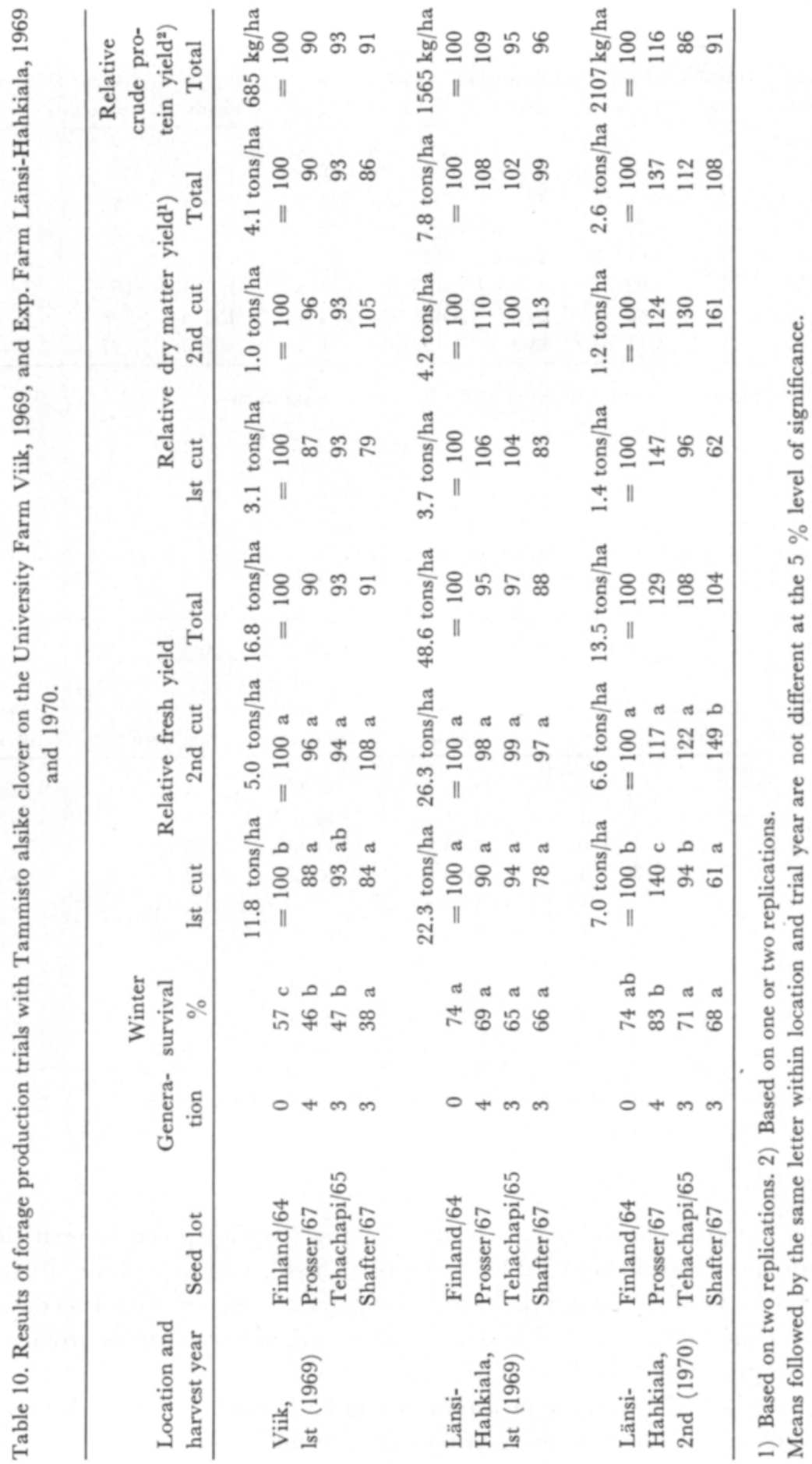




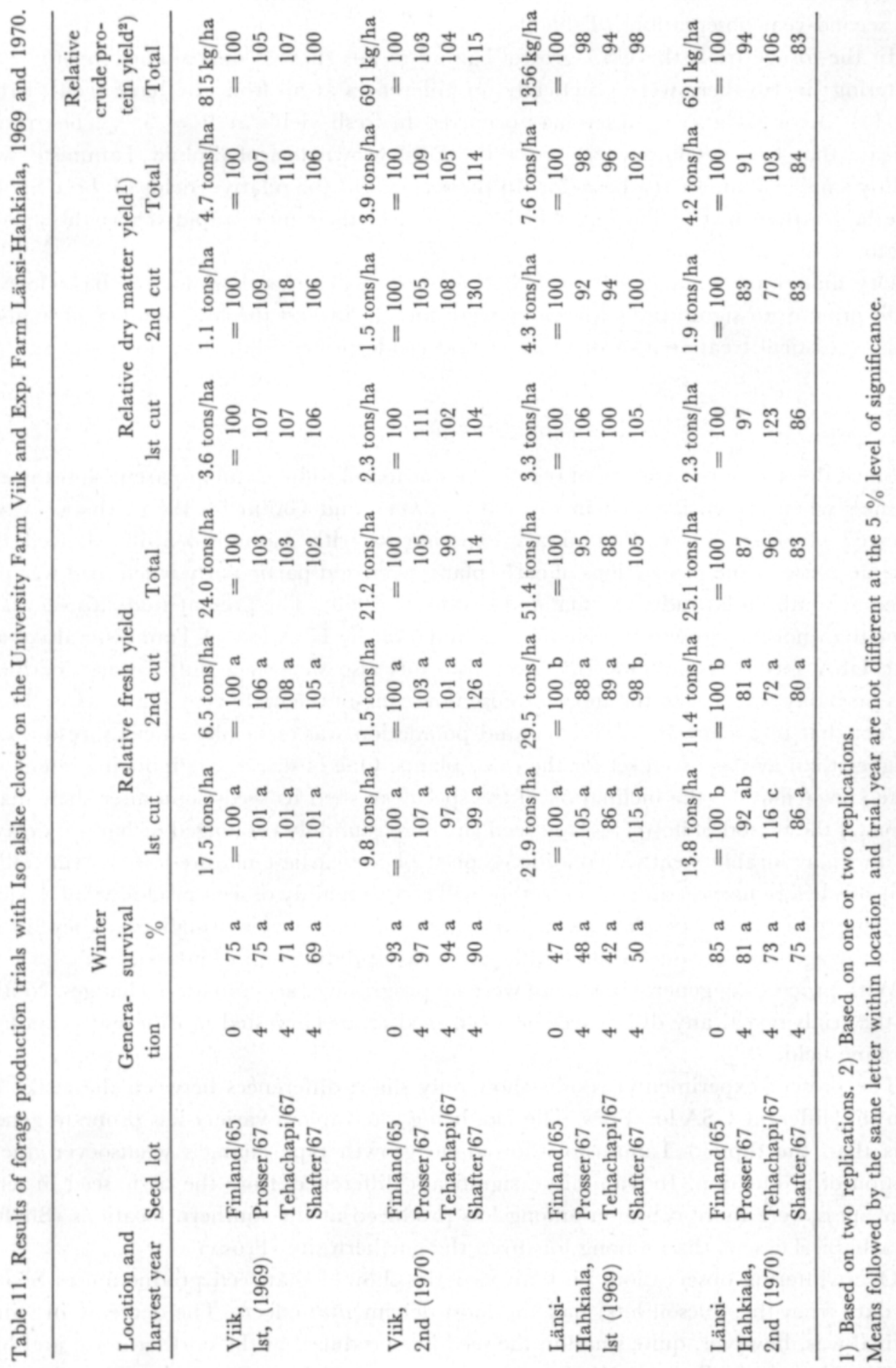


second-year flowering slightly later than the basic lot. Differences in flowering time were not significant, however. In the Iso alsike there was better agreement between the first and second-year observations (Table 9).

In the forage trials the USA-grown Tammisto lots showed only slightly poorer overwintering; in Iso there were practically no differences at all from the basic seed (Tables $10-11)$. Some significant differences occurred in fresh yields at $\mathrm{P}=5 \%$. The results indicate that first cut forage yields for the USA-grown lots of diploid Tammisto were slightly smaller than for the basic lot. In the second cut the relative yields of the USA lots were larger than in the first cut, which may reflect their more rapid regrowth capacity due to earliness.

Dry matter percentages for the USA lots were as high as those for the basic lots. In crude protein no significant differences were found. Due to the low number of analyses made, statistical treatment of dry matter and crude protein data was not possible.

\section{Discussion}

Since the Tammisto variety of red clover was found to incur an apparent shift towards earliness when grown for seed in the USA (VAlle and Garrison 1965), the same was expected of alsike clover. Preliminary experiments with Tammisto alsike showed that some decrease in the proportions of early plants occurred particularly when seed was produced at southern latitudes (VALLE and GARRISON 1959). The present study also revealed lower than normal growth type indices for some of the USA lots of Tammisto alsike and most USA lots of Iso. Yet many Tammisto lots also showed a shift towards earliness. This probably was due to the more profuse flowering of the early-type plants as well as to the fact that in a sparsely-flowering stand pollination was especially efficient, resulting in a higher than average seed set for the early plants. One of the factors inducing lateness in alsike clover may be the inclination of the species to shed its seeds soon after their maturation. If the period of flowering and seed ripening is unduly prolonged or harvest delayed due to unfavourable weather conditions, most of the earliest matured seeds will fall off the heads before harvest and the crop thus will consist mainly of seed produced by the lateflowering plants. - The changes in earliness were, however, so small that they do not affect the agronomic value of the seed lots in forage production in Finland.

With proceeding generations there were no progressive, accumulative changes. Neither did the trials reveal any differences between seed crops harvested in different years from the same field.

The present experimental results show only slight differences between the alsike lots from the different USA localities. The Iso, being a tetraploid variety less prone to genetic shifts than the diploid Tammisto, showed no growth type changes whatsoever due to location of production. In Tammisto, significant differences from the basic seed in terms of earliness were more common among lots produced at the southern locations (Shafter, Tehachapi, Tucson) than among lots from the northern site (Prosser).

Overwintering observations on both varieties showed that seed production in Shafter (no data from the Tucson lots) had the most detrimental effects. The decrease in winter survival was, however, quite small in the seed lots produced at the northernmost and high elevation locations, Prosser, Wash., and Tehachapi, Cal., respectively. Therefore seed 
produced in the USA for export to Finland should be grown in the north or at high elevations with cool temperatures.

Red and alsike clover varieties with early and profuse flowering have been found the most susceptible to winter injury (Smith 1957, 1963; Therrien and Smith 1960). Yet in the present trials the earliest USA lots of Iso alsike overwintered best. It should be noted, however, that the shift in Iso alsike clover was towards slightly later plant development. The earliest USA Iso lots, which overwintered best, did in fact resemble the Finnish basic seed more closely than did the Shafter lots which according to the growth type observations were latest of all but nevertheless showed the poorest winter survival.

Acknowledgment. The authors acknowledge the valuable contributions made to this study by Messrs. Clarence M. Rincker and John G. Dean, Research Agronomists, Plant Science Research Division, Agricultural Research Service, U. S. Department of Agriculture, Prosser, Washington; and Shafter and Tehachapi, California, respectively; and Dr. Martin A. Massengale, Professor of Agronomy, University of Arizona, Tucson, Arizona. They produced the 52 seed lots included in the evaluation trials in Finland, and determined the seed yields and components of yield at their respective centres. Also, to Professor Juhani Paatela, Department of Plant Husbandry, University of Helsinki, for his advice and continuing support of these studies.

\title{
REFERENCES
}

Ravantri, S. 1959. Tetra-alsikkeesta. Summary: Trials with Tetra alsike clover in Finland. Maatal. ja koetoim. 13: 187-192.

SмrтH, D. 1957. Flowering response and winter survival in seedling stands of Medium red clover. Agr. J. 49: 126-129.

Sмrтн, D. 1963. Reliability of flowering as an indicator of winter survival in red clover. Can. J. Plant Sci. 43: $386-389$.

Therrien, H. P. and Smith, D. 1960. The association of flowering habit with winter survival in red and alsike clover during the seedling year of growth. Can. J. Plant Sci. 40: 335-344.

VAlle, O. \& Garrison, C. S. 1959. Seed production of Finnish Tammisto alsike clover in southern latitudes. Ann. Acad. Sci. Fenn. A IV Biol. 47: 1-16.

VAlle, O. \& Garrison, C. S. 1965. Experiences with seed production of Finnish single-cut Tammisto red clover in the USA. Proc. 9th int. Grassl. Cong. 535-541.

\section{SELOSTUS}

\section{USA:SSA SIEMENVILJELLYISSÄ SUOMALAISISSA ALSIKEAPILALAJIKKEISSA TODETUISTA MUUTOKSISTA}

\author{
Otto Valle, Kirsti Äyräväinen ja C. S. Garrison \\ Helsingin yliopiston kasvinviljelytieteen laitos
}

Plant Science Research Division, Agricultural Research Service, U. S. Department of Agriculture

Suomalaisista alsikeapilalajikkeista, diploidista Tammistosta ja tetraploidista Isosta, USA:ssa neljässä perättäisessä polvessa tuotettuja siemeneriä tutkittiin Suomessa suoritetuissa yksilö- ja rehuntuotantokokeissa tarkoituksella selvittää mitä muutoksia siemenviljely USA:ssa oli lajikkeissa aiheuttanut.

Aikaisia, kasvutyypiltäån pieniruusukkeisia yksilöitä kehittyi USA:ssa tuotettuihin Tammiston alsik- 
keen eriin keskimäärin enemmän kuin verranteena olevaan perussiemenerään. Eri vuosina esiintyi Tammiston alsikkeen koetuloksissa kuitenkin huomattavan suurta vaihtelua. Iso-alsikkeen USA:ssa tuotetut erät poikkesivat harvemmin perussiemenerästä, ja poikkeavissa erissä oli, päinvastoin kuin Tammistossa, perussiementä pienempi keskimääräinen kasvutyyppi-indeksi ja vähemmän kukkivia yksilöitä.

Tuorepainossa ja verso- ja mykeröluvussa ei todettu eroja USA:ssa tuotettujen erien ja verranne-erien välillä. Yksilöiden jälkikasvu oli USA:n erissä niinikään jokseenkin perussiemenen veroinen.

Talvenkestävyys oli useissa USA:ssa tuotetuissa erissä kuitenkin perussiementä heikompi. Heikoimmin talvehtivat Shafterissa, Kaliforniassa tuotetut erät. Talvehtimishavaintojen perusteella erottui Shafter kummassakin lajikkeessa muita suomalaisten lajikkeiden amerikkalaisia siemenviljelypaikkakuntia epäedullisempana siemenviljelypaikkana. Muiden havaintojen perusteella ei paikkakuntien välillä ollut eroja.

Perättäisissä polvissa ei todettu lisääntyviä muutoksia perussiemeneen verrattuna. Samasta kasvustosta kahtena vuonna korjattujen siemenerien välillä ei myöskään ollut merkitseviä eroja.

Yksilökokeissa todetut muutokset aikaisuudessa olivat satunnaisia ja niin vähäisiä, etteivät ne vaikuta tuotetun siemenen käyttöarvoon Suomessa. Aikaisuuden lisääntymiseen oletettiin syyksi aikaisten yksilöiden muita runsaampi kukinta ja tehokkaampi pölytys siemenviljelyksillä ja aikaisuuden vähenemiseen kypsyneen siemenen taipumus varista herkästi.

Talvenkestävyyden aleneminen oli myöskin varsin vähäistä etenkin siemenerissä, jotka oli tuotettu pohjoisimmalla viljelypaikkakunnalla Prosserissa, joka lähinnä vastaa viljelyoloiltaan niitä seutuja, joilla käytännön siemenviljelyä Suomeen vientiä varten saatettaisiin harjoittaa.

Rehukokeiden suppeassa aineistossa ei myöskään esiintynyt sellaisia eroja, jotka olisivat osoittaneet USA:ssa tuotetun siemenen olevan rehuntuotannossa perussiementä heikompaa. 